\title{
CHANGES IN TECHNICAL SUPPORT ON FARMS OF LATVIA
}

\author{
Nikolajs Kopiks, Dainis Viesturs, Adolfs Rucins \\ Latvia University of Life Sciences and Technologies, Latvia \\ viesturs_uzc@apollo.lv
}

\begin{abstract}
The article reveals trends in the development of the tractor fleet on the farms of various sizes in a tenyear period 2007-2016. A decrease has been established in the number of farms, the planting areas and the number of tractors on farms with sown areas below 50 ha, but these indicators are increasing on farms with areas under crop over 50 ha. The total capacity of tractors on the farms with a sown area over 50 hectares has increased by $70 \%$, while on the farms with an area of 50 ha it has changed insignificantly. With the agricultural sown areas increasing, the specific capacity $\mathrm{kW} \cdot \mathrm{ha}^{-1}$ of tractors is decreasing, which indicates intensive use of the machinery. It is characteristic for the country that the average age of the registered tractors is 24.4 years; however, this depends on the registration peculiarities of the tractors. The farms with areas under crop over 50 hectares work with modern machines.
\end{abstract}

Keywords: fleet of tractors, power, technical condition.

\section{Introduction}

The area of land used in the country and production there is gradually increasing; the total area under crops in 2007-2016 has increased 1.10 times. In their turn, the areas of the cereal and canola sowings have increased 1.25 times, and the total harvest 1.72 times. The production of milk, meat and other products has increased as well [1]. It is typical that production is concentrated on larger farms the total number of farms and agricultural enterprises with an area of up to 50 ha are decreasing, but the number of farming enterprises with an area of over 50 ha is rising [2], which also changes the requirements for tractors and other agricultural machines. There are studies on the compatibility of the total capacity of the tractor fleet with the increasing amount of production [3], the maintenance costs of machinery [4;5], the efficiency of the use of different types of tractors [6]. However, there are no investigations about the provision with tractors, their capacity, the intensity of their use on various size farms, especially on farms with an area of more than 50 hectares, the number of which is increasing and which acquire mainly new tractors. The purpose of the article is to evaluate the changes in the number of tractors, their capacity, and their capacity per hectare $\mathrm{kW} \cdot \mathrm{ha}^{-1}$ during a ten-year period on farms of various sizes, and to assess the age structure and the renewal rate of the entire tractor fleet during this period. By analysing the obtained data it is possible to judge about the future changes in the farmland areas and requirements for the tractors purchased in the future within the context of these changes.

\section{Materials and methods}

Due to the availability of structural funds after Latvia's entrance into the EU, the purchase of modern tractors has increased significantly. On the average, during the period 2007-2016 there were purchased 597 new tractors annually. In the statistics of the Central Statistical Bureau [2] one can find data about the sown areas, the number and brands of tractors on the farms of various sizes and their total number at these enterprises. In their turn, data about the tractor capacity, age and technical condition, as well as about the tractors annually registered in 2007-2016 can be found in the State Technical Control Agency reports [7]. These data were analysed, grouped, processed and interpreted using the mathematical statistics methods. Data about the number of tractors, average capacity and distribution of the capacity per hectare $\mathrm{kW} \cdot \mathrm{ha}^{-1}$ were obtained depending on the size of the farms, the age structure of the tractors and the renewal rate of the tractor fleet.

\section{Results and discussion}

During the last 10 years (2007-2016) on the farms having sown areas there occurred changes in the number of tractors, their total and average capacity. Since the amount of the performed work depends in many respects on the efficiency of the use of tractors, we will further consider the above indicators on farms with different sizes of sown area. Figure 1 shows a change in the number of tractors and their average capacity depending on the sown area of the farm. 
Analysis of the data indicates that in 2016, in contrast to 2007, the total number of tractors had decreased by $9 \%$ (the number of tractors in 2016 was 50492). However, these changes on the farms with different areas under crop are of a different nature. On the farms having an area below 50 hectares the number of tractors decreased by $19 \%$, but on the farms with a sown area of more than 50 hectares it increased by $33 \%$. Since the number of small farms with a sown area of 50 hectares is much larger than the number of farms with an area of 50 hectares and more, the total number of tractors has decreased, too. The average capacity of the tractor increased in all groups of farms, and on the farms with a sowing area less than 50 hectares it was $59 \mathrm{~kW}$, but on the farms with more than 50 hectares it was $89 \mathrm{~kW}$, which is correspondingly higher by $24 \%$ and $26 \%$ in comparison with the year 2007.

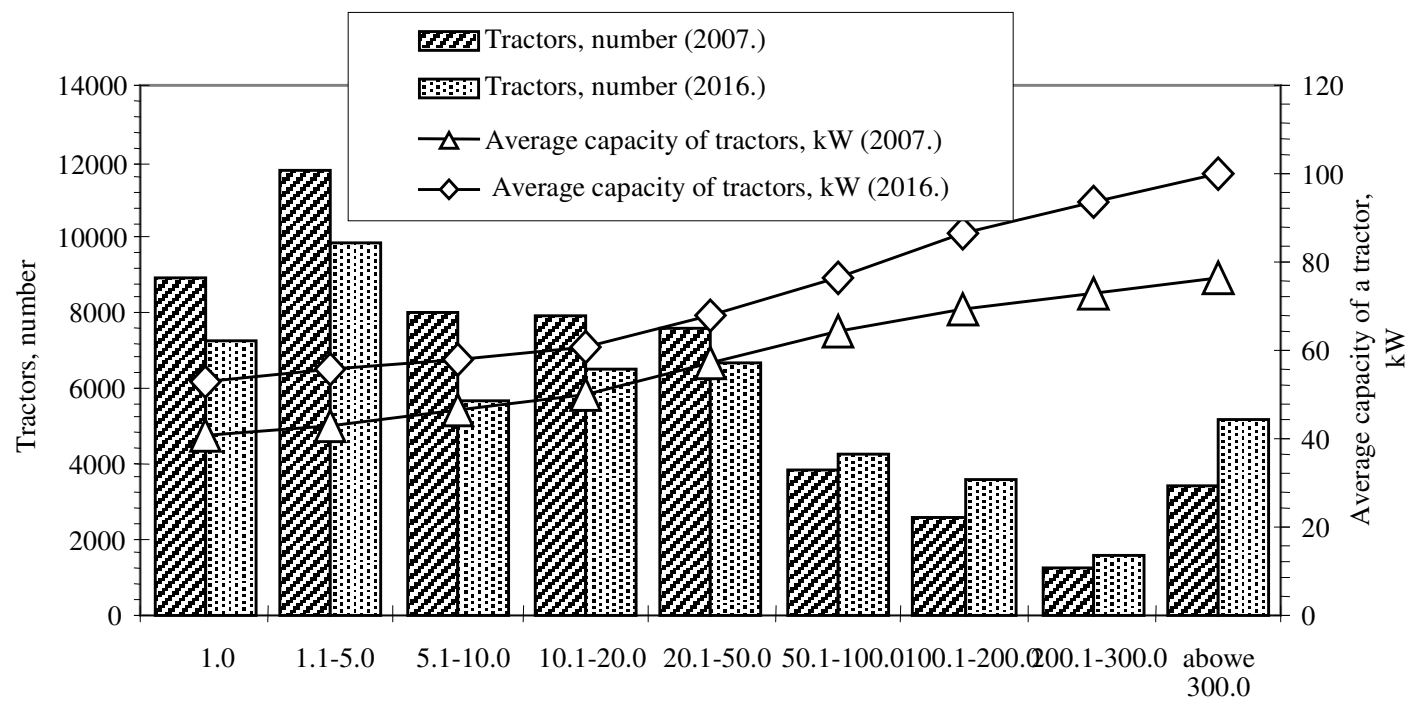

Sown areas in the groups of farms, ha

Fig. 1. Number and average capacity of tractors in groups of farms with different sizes of sown area (2007-2016)

In the period of 2007-2016 the total capacity of tractors in all the groups of farms increased by $20 \%$. However, on the farms with a sowing area of up to 50 hectares, there was an increase of $1.5 \%$, and on the farms with an area of more than 50 hectares, it was $70 \%$. These data witness that the specific energy intensity of large farms is increasing and this contributes to the increase in the labour productivity and improvement of economic indicators. It follows from the analysis that, due to the consolidation of farming enterprises, specific energy intensity will grow in the future also on the farms with the sown areas of more than 50 hectares; the average power of a tractor and their number will increase.

The change in the structure of the tractor fleet, the increase in the tractor capacity can largely be explained by the integration of the farms. Figure 2 shows the change in the sown area and the capacity per hectare in different groups of farms. In the period 2007-2016 the total area under crop at all the agricultural enterprises increased by $18 \%$ (in 2016 - 1231 thousand hectares). In addition, on the farms with less than 50 hectares, the sown area decreased by $37 \%$, and on the farms with more than 50 hectares it increased by $55 \%$, as compared with the year 2007. The number of farms in different groups also changed, the number of farms with an area of less than 50 hectares diminished by $51 \%$, but the number of farms having more than 50 hectares went up by $28 \%$. The capacity of tractors per hectare is decreasing with the increase in the sown areas of the farms, but the efficiency is increasing at the expense of the purchased more powerful tractors. It is typical that on farms with an area of more than 300 ha - with the most intensely used machinery - the capacity per hectare constitutes $0.9 \mathrm{~kW} \cdot \mathrm{ha}^{-1}$, which is a good indicator in contrast to other countries [8]. The number of such farms is $1.7 \%$, and their sown area makes $48 \%$ of the total area. 


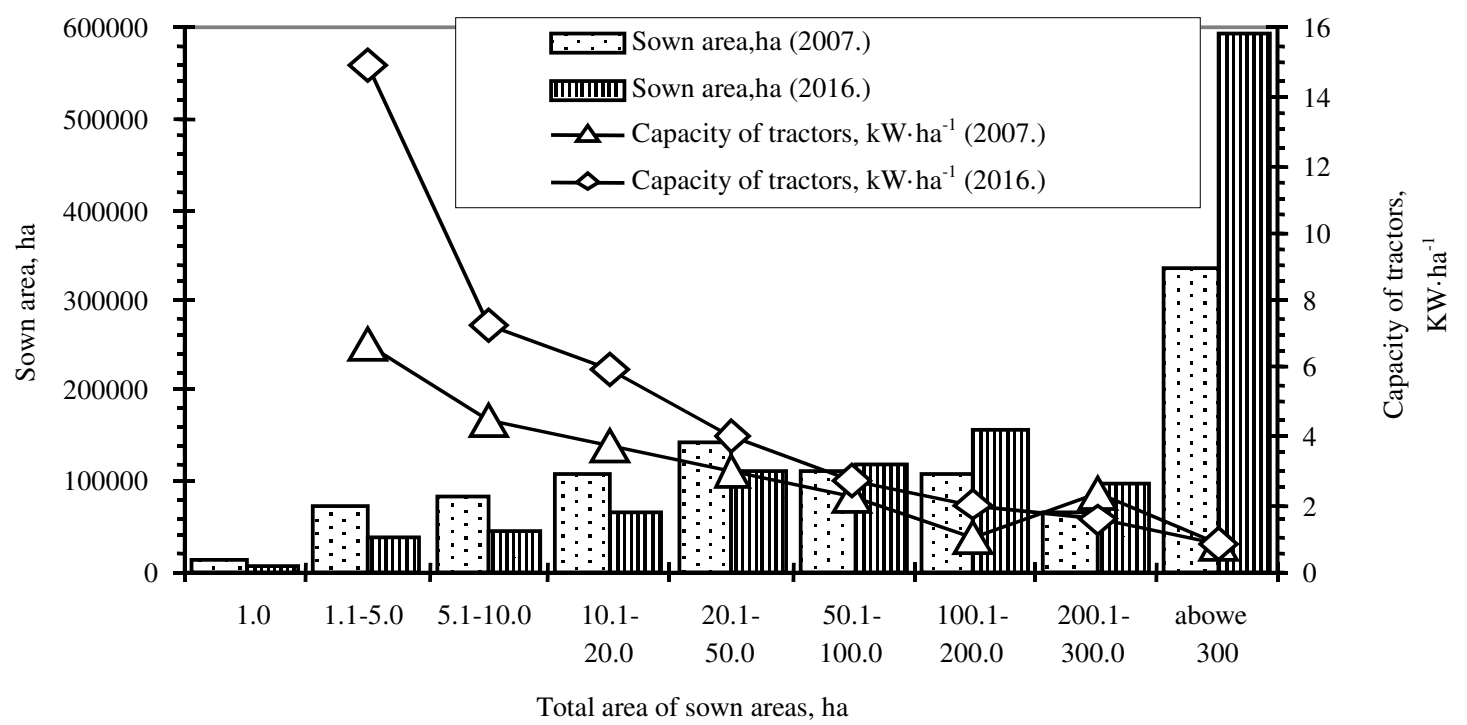

\section{Fig.2. Sown area and capacity per hectare in groups of farms with different sizes of sown area (2007-2016)}

The possibility to use machines and the increased efficiency at the expense of the growing capacity depends to a great extent on their age structure because, when the age of the machinery becomes shorter, the duration of its efficient work, the degree of its power use and its efficient service ability diminishes, too. Figure 3 reflects the distribution of tractors as a percentage of their total number by the age periods in agriculture (2016.).

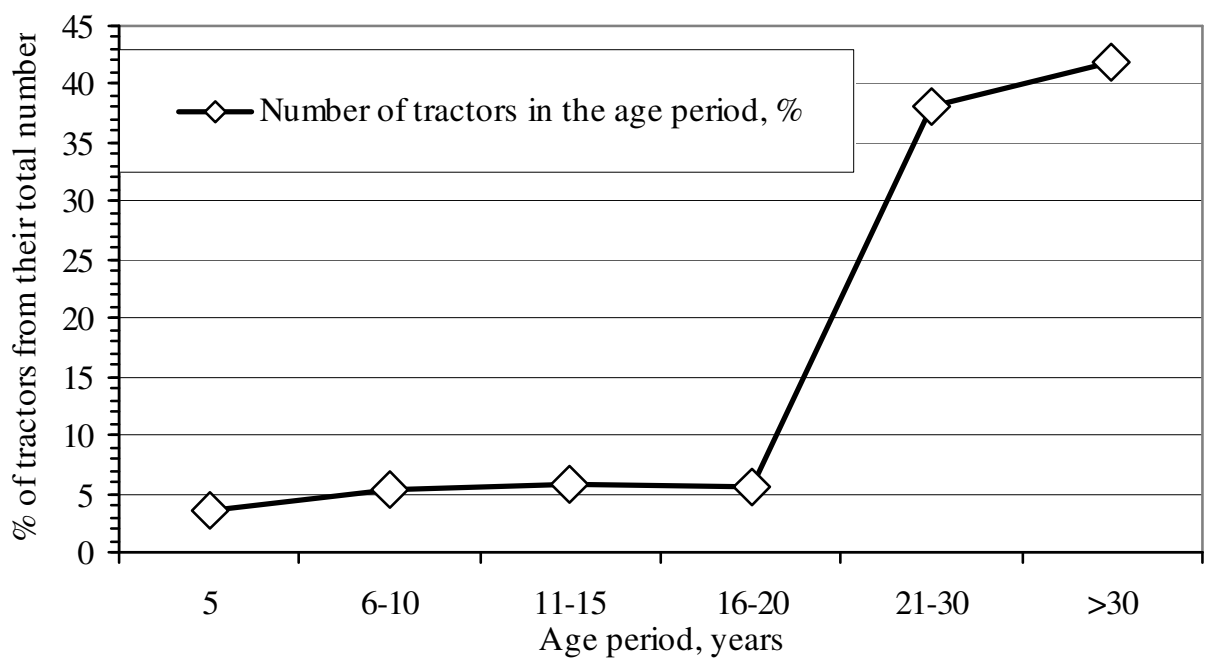

Fig. 3. Distribution of tractors as percentage of their total number by age periods in agriculture (2016)

From the maximum number, $42 \%$ of tractors are more than 30 years old, $38 \%$ are 21-30 years and only $14.5 \%$ of tractors are under the age of 15 years, $34 \%$ of tractors having passed technical inspection in the recent years.

The average age of tractors increases each year by about $1.3 \%$. This is because the out-of-date tractors are not excluded from the State Technical Inspection Register. Elimination of the tractor from the Register requires time and monetary means from the owner, but its presence in the Register does not impose any obligations. More than half of the registered tractors are brands MTZ, T-25, T-40, which explains the large quantity of tractors, older than 30 years. In reality, on the farms with an area of more than 50 hectares, producing goods for the market, there are working up to 15-20 years old 
tractors, which constitute approximately $20 \%$. The out-of-date tractors are used on the household plots and on farms with small sown areas.

During the period of 2007-2016 the farms have purchased 597 new tractors a year, although in the recent years their purchase is declining. The renewal rate of the tractor fleet should be considered satisfactory - this is evidenced by an increase in the average capacity, especially on farms with areas of more than 50 hectares (Fig. 1) and a decline in the purchase in the recent years. This is also confirmed by a previous study by the authors of [3], which shows that the increase in the total capacity of the tractor fleet outpaces the growth of the areas under crop and production.

\section{Conclusions}

1. During the period of 2007-2016 the total sown area and the number of tractors decreased on the farms with an area less than 50 hectares and increased on the farms with an area of more than 50 hectares, which indicates the concentration of production.

2. The total capacity of the tractor fleet on the farms with an area of more than 50 hectares increased by $70 \%$, which confirms the intense use of the machinery, high efficiency and the expected capacity increase in the perspective.

3. The large average age of the tractor fleet -24.4 years - is determined by the registration peculiarities of the tractors. However, on the farms with an area of more than 50 hectares, there work mainly up-to-date tractors with an age of up to 15-20 years.

\section{References}

[1] LR Centrālās statistikas biroja materiāli "Lauksaimniecība, mežsaimniecība, zivsaimniecība". Ikgadējie dati - Laukkopība. Lopkopība. 2007... 2016.g. (Materials of the Central Statistics Bureau of Latvia Annual data - Agriculture, Forestry, Fish Farming. 2007... 2016.) (In Latvian).

[2] LR Centrālās statistikas biroja materiāli "Lauksaimniecība, mežsaimniecība, zivsaimniecība". Lauku saimniecību struktūra 2007... 2016.g. (Materials of the Central Statistics Bureau of Latvia "Agriculture, Forestry, Fish Farming". Structure of agricultural enterprises 2007...2016). (In Latvian).

[3] Viesturs D., Kopiks N. Trends in development of tractor fleet in Latvia. In: 16th International scientific conference "Engineering for rural development": proceedings, Jelgava, Latvia, May 24 26, 2017. Jelgava, 2017. Vol.16, pp. 534-539,

[4] Olt J., Traat U., Kuut A. Maintenance Costs of Intensively Used Self-Propelled Machines in Agricultural Companies. In: 9th International Scientific Conference "Engineering for Rural Development": proceedings Jelgava, Latvia, May 27-28, 2010, Latvia University of Agriculture. Faculty of Engineering. Jelgava, 2010. Vol.9, pp. 42-48.

[5] Barvicki J., Gach S., Ivanovs S. Proper utilization of soil structure for crops today and conservation for future generations. In: 11th International Scientific Conference "Engineering for Rural Development", proceedings, Jelgava, Latvia, May 24-25, 2012, Latvia University of Agriculture. Faculty of Engineering. Vol. 11, pp. 10-15.

[6] Bulgakov V, Nadykto V., Velichko I., Ivanovs S. Investigation of draft coefficient of efficiency of wheeled tractor. In: 15th International scientific conference "Engineering for rural development": proceedings, Jelgava, Latvia, May 26-27, 2016, Latvia University of Agriculture. Faculty of Engineering. Jelgava, 2016. Vol.15 pp.1036-1041.

[7] Valsts Tehniskās uzraudzības aǵentūras pārskati 2007... 2016.g. (Reviews of the State Technical Control Agency 2007...2016), Rīga, Zemkopības ministrija. (In Latvian)

[8] Pawlak J., Pelizzi G., Fiala M. On the Development of Agricultural Mechanization to Ensure a Long-Term World Food Supply. Agricultura/ Engineering International: the CIGR Journal of Scientific Research and Development. Invited Overview Paper. Vol. IV, June 2002, pp. 1-21. 